\title{
Impact of Pesticides on the Diversity of Fungi at Local Shallot in Palu, Indonesia
}

\author{
Ratnawati Ratnawati $^{1 *}$, Sylvia Sjam ${ }^{2}$, Ade Rosmana ${ }^{2}$ and Untung Surapati Tresnaputra ${ }^{2}$ \\ ${ }^{1}$ Agrotechnology Alkhairaat University Palu, Central Sulawesi, Indonesia \\ ${ }^{2}$ Plant Pests and Diseases, Faculty of Agriculture Hasanuddin University Makassar, \\ Indonesia \\ *Corresponding author
}

\begin{abstract}
A B S T R A C T
Keywords

Rhizosphere, phylosphere, Fusarium sp., Trichoderma spp., Aspergillus niger

Article Info

Accepted:

07 July 2019

Available Online:

10 August 2019

Intensive pesticide application caused damaged of natural balance in agricultural land. Purpose of the study is to evaluate frequency of pesticides application and their impact presence of fungi at local shallot plants in Oloboju village, Sigi Regency, Central Sulawesi. Almost all of local shallot farmers was used synthetic pesticides controlled pests and diseases with high, medium and low of their frequency applications. By comparing final application of pesticides, the results was showed increasing pesticides application can reduced fungi index diversity in rhizosphere and phylosphere by approximately 0.5623 and 0.6002 , respectively. It compared with frequency of pesticides application in low and medium with a diversity index value about 1.332 and 1.696 in rhizosphere, different in phylosphere result at 1.56 and 1.889 . The similar application was showed the evenness index and species richness index of rhizosphere and phylosphere. The impact application of pesticides was showed a resistant fungi species such as Fusarium sp. as a pathogenic fungi and found in all of frequencies pesticide application. The presence of Trichoderma spp. and Aspergillus niger as endophytic fungi at all of frequencies pesticide application, giving important information and very useful for this study. Antagonistic fungi and their existence in local shallot field can be developed to be biological agents, because they have survival properties in environments with varying levels of pesticide residues.
\end{abstract}

\section{Introduction}

Shallot (Allium cepa var. aggregatum) a famous local varieties from Palu valley are one of the important commercial vegetable crops in Central Sulawesi, Indonesia. These commodities are quite well known as source of raw materials in manufactures of fried shallot products that savory taste and delicious. Based morphology performance such as bulbs rather pink and white color, the typical of local shallot from Palu valley almost similar in general, but they are small size.
Average harvest of local shallot still lower, accompanied by high demand and good prices. This is main reason farmers continue planting these commodities on their land every years (Maskar et al., 1999; Shahabuddin et al., 2012 and Saidah et al., 2014). The low harvest of local shallot production because application of cultivation techniques less supportive beside presence plant pests and diseases.

Commonly few pests found in the field such as: mole cricket (Gryllotalpa sp.), army worm (Spodoptera litura L.), onion caterpillar 
(Spodoptera exiqua), leafminers (Liriomyza chinensis) and thrips (Thrips tabaci). The important diseases on shallot including: Fusarium wilt (Fusarium oxysporum), downy mildew (Peronospora destructor), antraknose (Colletotrichum gloeosporiodes), leaf spots (Cercospora duddiae). The dominan disease in the field are purple spot (Alternaria porrii) (Semangun, 2006; Ratnawati and Idris, 2010; Rusdam et al., 2013; Marlitasasri et al., 2016).

The economic implications of the damage and loss of shallot harvest based presence plant pests and diseases encourage farmers used high frequency pesticides application. Pesticides are still considered by shallot farmers in the Palu valley as a savior of production from pests attack (Jaya et al., 2015). The increasing of total concentration by farmers used reaching approximately 150 $200 \%$ higher than the recommended level by mixing two or three types of pesticides at once application (Basuki, 2011; Waryanto et al., 2014). This intensive of pesticides application was resulted in several ecological consequences for the environment such as resistance to pests and diseases, potential decreases in soil quality, negative impacts on other creatures, including antagonistic fungi and high chemical residues in shallot bulbs (Basuki, 2011; Nelly et al., 2015 and Joko et al., 2017).

The use of microorganisms as biological control agents needs to be pursued continuously and ideally using the potential of local natural enemies. This microorganisms will work more effectively and supported by appropriate environmental factors. They are keep ecosystem changes and cheaper formulations for farmers. According to Cook and Baker (1983), efforts control plant diseases by biological means have a fairly bright opportunity because the microorganisms are available in nature and their activities can be stimulated by environmental and host modifications. The group of fungi microorganisms that potentiap suppress pathogens, especially in family Moniliales, such as Verticillum sp., Trichoderma spp. and Gliocladium sp. Genus Trichoderma spp. has several species parasitized other fungi and very potential as biological control agents (Santoso et al., 2007). However, disturbances in the existence, diversity and abundance was affected ecosystems including soil fertility, microorganism populations and populations of plant pests and diseases.

Based on the risk of pesticides application on local shallot at Palu valley, the purpose of the study to evaluate pesticides application by farmers, to determine the diversity, wealth and abundance of phosphorus fungi and zyzosphere as an impact of pesticides. The data collected from the study will be useful designing Integrated Pest Management (IPM) on local shallot in Palu valley.

\section{Materials and Methods}

The research was conducted from January to June 2018 located in Oloboju Village, Seromiromaru, Sigi district. The place is the centre of local shallot plantations in Palu valley, Central Sulawesi. The another treatment was continued at Laboratory of Disease Sciences, Faculty of Agriculture, Hasanuddin University Makassar.

\section{Survey and sampling of local shallot farmers}

The survey was conducted in interview purpose to determine the level pesticides application of local shallot farmers in Palu valley. According to previous observational data and interviews with local agricultural extension workers, there are around 300 shallot farm families in the village. Approximately ten percent of pupulation (30 
farmers) as samples for interviews about the landas on the shallot land area owned, the frequency of pesticide use per season is around 60 days, and the type of pesticide used. From interviews it was described 3 farmers only used herbicides and natural pesticides, 13 farmers used pesticides less than ten times, and 14 farmers applied more than ten times per season.

The frequency of application of pesticides to local shallot was categorized as each application is low, medium, and high. The data was added observation sample rhizosphere and phylosphere. The local shallot samples are taken from the farmers' field. Sampling was used purposive sampling method, which is taking samples of onion plants at ten points diagonally at each stage with several categories level pesticides application. The local shallot was removed and put into plastic bag clip, labeled and stored in the cooler box for laboratory activities.

\section{Fungi Isolation}

Fungi from similar field with local shallot was isolated based Nirwanto (2007). In laboratory, each soil sample from rhizosphere weighed 10 gr, then dilution to concentration $10^{-4}$ cfu. Each of fungi sample measure $0.1 \mathrm{ml}$ was cultured in Potato Dextrose Agar (PDA) and incubated at room temperature 3 - 14 days. Different colonies of fungi that grew on PDA was counted, isolated and purified as a stock culture. The fungi from the rhizosphere was labeled. The phylosphere sample was cutting long $1 \mathrm{~cm}$ then surface sterilization using $0.5 \% \mathrm{NaOCl}, 70 \%$ ethanol and distilled water for 1 minute, respectively. Samples then dried by clamping between sterile tissue paper. The sample was cultured in PDA then incubated at room temperature for 3-14 days. The growing of colonies fungi from phylosphere was counted, isolated and purified.

\section{Shannon-Wiener Index Diversity}

Fungi diversity index from rhizosphere and phylosphere was calculated by ShannonWiener index diversity (H ') (Magurran, 1983).

$\mathrm{H}^{\prime}=-\sum_{i=1}^{s} p i \operatorname{Ln} p i$

Variables:

$\mathrm{H}^{\prime}=$ Shannon - Wiener diversity index.

$\mathrm{S}=$ number of species in the community (richness).

$\mathrm{Pi}=$ the proportion first species in the total individuals in the sample.

$\ln =$ natural logarithm.

\section{Index of Individual Abundance}

Index of individual abundance was calculated by Simpson index diversity (D) (Magurran, 1983)

$D=-\sum_{i=1}(n i(n i-1) /(N-1)$

Variables:

$\mathrm{ni}=$ individual species number.

$\mathrm{N}=$ total individual number

Margalef species richness indeks (Ludwig dan Reynolds, 1988)

Fungi species richness index was calculated by Margalef index $(\mathrm{R})$ :

$R=\frac{S-1}{\ln (n)}$ 
Variables:

$\mathrm{R}=$ species richness index

$\mathrm{S}=$ measurement species number

$\mathrm{N}=$ Total individual number

$\mathrm{Ln}=$ natural logarithm

\section{Results and Discussion}

\section{Pesticides application by farmers for local shallot}

Oloboju village as the study site in Sigi Regency known as the Palu valley. The majority of the population is local shallot farmers with approximately 300 family farm in areas 286 ha. Local shallots was planted continuously in four planting season per year. The methods controlling pests and diseases was showed about $46.7 \%$ farmers used synthetic pesticides with more than ten times the frequency of application per planting season; $43.3 \%$ farmers was used less than ten times pesticides; only $10.0 \%$ use natural pesticides, respectively (Table 1 and 2). About $10 \%$ farmers was used herbicides controlled weeds and natural pesticides from neem controlled pests and diseases.

The type of pesticides including fungicides and insecticides was showed in Table 3. The fungicides was used are generally classified as pesticides that do not cause acute harm in regular use (U), while insecticides used are generally classified as quite dangerous (II), and one of them is very dangerous (Ib). All these pesticides was controlled pests and diseases of local shallot.

\section{Pesticides Impact on Fungi}

The pesticides application by farmers on local shallot has impact the presence of fungi in field. The result of fungi identification and the number of isolates are shown in Table 4.

Table 4 was showed more isolates were found in high frequency of pesticide application, but generally unidentified isolates with relative low diversity index, in rhizosphere and phylosphere. Fungi index diversity including abundance and species richness of fungi in plantation of local shallot farmer in Oloboju village (Table 5).

Increasing demand the local shallot from Palu valley as raw material for Palu's typical fried shallot in Central Sulawesi, caused farmers planting throughout the year. This activities caused increasing pest attacked plant in Oloboju village as the main source of local shallots. Effort controlled presence of pests was identified approximately $90 \%$ farmers used synthetic pesticides. Pesticides not used based recommended dosage at application in every week. This is potential caused outbreak of secondary pests, killed natural enemies and resistance diseases on the field.

Table.1 Indicator of Shannon-Wiener Indeks Diversity (H')

\begin{tabular}{|c|c|c|}
\hline$H^{\prime}<\mathbf{1 . 0}$ & $1.0<H^{\prime}<3,322$ & $H^{\prime}>\mathbf{3 , 3 2 2}$ \\
\hline $\begin{array}{l}\text { * species diversity is classified } \\
\text { as lower; }\end{array}$ & $\begin{array}{l}* \text { species diversity is } \\
\text { classified as moderate; }\end{array}$ & $\begin{array}{l}\text { * species diversity is } \\
\text { classified as higher; }\end{array}$ \\
\hline \multirow{2}{*}{$\begin{array}{l}* \text { Poor (very low productivity) } \\
\text { as an indication of heavy } \\
\text { ecological pressure; }\end{array}$} & *medium productivity; & *stability of the ecosystem; \\
\hline & $\begin{array}{l}\text { *The condition of the } \\
\text { ecosystem is quite balanced; }\end{array}$ & *high productivity \\
\hline *Unstable ecosystem & $\begin{array}{l}\text { *medium ecosystem } \\
\text { pressure; }\end{array}$ & \\
\hline
\end{tabular}


Table.2 Frequency of pesticide application in level of onion farmers

\begin{tabular}{|c|c|c|c|}
\hline $\begin{array}{c}\text { Number of } \\
\text { respondent }\end{array}$ & $\begin{array}{c}\text { Frequency of } \\
\text { pesticide application }\end{array}$ & Percentage & Level \\
\hline $\mathbf{1 4}$ & $\geq 10$ times & 46.7 & High \\
\hline $\mathbf{1 3}$ & $<10$ times & 43.3 & Medium \\
\hline $\mathbf{3}$ & once (herbicide) & 10 & Low \\
\hline & $\mathbf{3 0}$ & & 100 \\
\hline
\end{tabular}

Table.3 Pesticides Active Compound was used by Local Shallot Farmers

\begin{tabular}{|c|c|c|c|}
\hline Type of Pesticides & Active Compound & Group & Class \\
\hline Fungicide & Ziram & Dithiocarbamate & III \\
\hline Fungicide & Mancozeb & Dithiocarbamate & U \\
\hline Fungicide & Propineb & Dithiocarbamate & U \\
\hline Fungicide & Carbendazim & Benzimidazole & U \\
\hline Fungicide & Phosphorous acid & Phosphonate & U \\
\hline Fungicide & Thiophanate-methyl & Benzamidazole & U \\
\hline Fungicide & Prochloraz & Imidazole & III \\
\hline Fungicide & Iprodione & Dicarboximide & U \\
\hline Insecticide & Chlorpirifos & Organophosphate & II \\
\hline Insecticide & Alpha-cypermethrin & Botanical & II \\
\hline Insecticide & BPMC & Carbamate & II \\
\hline Insecticide & Methomyl & Carbamate & Ib \\
\hline Insecticide & Chlorantraniliprole & Antranilicdinamide & U \\
\hline Insecticide & EmamectinBenzoat & Avermectin & U \\
\hline Insecticide & Chlorfenapyr & Pyrrole & II \\
\hline Insecticide & Carbosulfan & Carbamate & II \\
\hline Herbicide & Paraquat & Piridin & II \\
\hline
\end{tabular}

$\mathrm{Ia}=$ Extremely hazardous; Ib = Highly hazardous; II = Moderately hazardous; III = slightly hazardous; U = Unlikely to present acute hazard in normal use; $\mathrm{FM}=$ Fumigant, not classified; $\mathrm{O}=$ Obsolute as pesticide, not classified.

Table.4 Fungi Identification and Number of Isolates

\begin{tabular}{|c|c|c|c|c|c|c|c|c|}
\hline \multirow{3}{*}{ No. } & \multirow{3}{*}{$\begin{array}{l}\text { Fungi } \\
\text { Species }\end{array}$} & \multicolumn{6}{|c|}{ Frequently of Pesticide Application } & \multirow[t]{3}{*}{ Status } \\
\hline & & \multicolumn{2}{|c|}{ Low } & \multicolumn{2}{|c|}{ Medium } & \multicolumn{2}{|c|}{ High } & \\
\hline & & $\begin{array}{l}\text { Rhizo } \\
\text { sphere }\end{array}$ & $\begin{array}{l}\text { Phylo } \\
\text { sphere }\end{array}$ & $\begin{array}{l}\text { Rhizo } \\
\text { sphere }\end{array}$ & $\begin{array}{l}\text { Phylo } \\
\text { sphere }\end{array}$ & $\begin{array}{l}\text { Rhizo } \\
\text { sphere }\end{array}$ & $\begin{array}{l}\text { Phylo } \\
\text { sphere }\end{array}$ & \\
\hline 1. & $\begin{array}{l}\text { Aspergillus } \\
\text { niger }\end{array}$ & 2 & 1 & 1 & 1 & - & 2 & Endophyte \\
\hline 2 & $\begin{array}{l}\text { Aspergillus } \\
\text { flavus }\end{array}$ & - & 2 & 1 & 1 & - & - & Endophyte \\
\hline 3 & Fusarium sp. & - & 1 & 3 & 2 & - & 1 & Pathogen \\
\hline 4 & $\begin{array}{l}\text { Gliocladium } \\
\text { sp. }\end{array}$ & - & - & - & 1 & - & - & Endophyte \\
\hline 5 & $\begin{array}{l}\text { Penicillium } \\
\text { sp. }\end{array}$ & 1 & 2 & 1 & 1 & - & - & Endophyte \\
\hline 6. & $\begin{array}{l}\text { Trichoderma } \\
\text { sp. }\end{array}$ & 1 & - & 2 & 2 & 1 & - & Endophyte \\
\hline 7 & Unidentified & 1 & 2 & 2 & 1 & 3 & 9 & - \\
\hline \multicolumn{2}{|c|}{ Total number } & 5 & 8 & 10 & 9 & 4 & 11 & \\
\hline
\end{tabular}


Table.5 Fungi Index Diversity Analysis on the Local Shallot at Oloboju Village

\begin{tabular}{|l|c|c|c|c|c|c|}
\hline \multirow{2}{*}{ Index diversity analysis } & \multicolumn{5}{|c|}{ Frequently of Pesticide Application } \\
\cline { 2 - 7 } & \multicolumn{2}{|c|}{ Lower } & \multicolumn{2}{c|}{ Medium } & \multicolumn{2}{c|}{ High } \\
\cline { 2 - 7 } & $\begin{array}{c}\text { Rhizo } \\
\text { sphere }\end{array}$ & $\begin{array}{c}\text { Phylo } \\
\text { sphere }\end{array}$ & $\begin{array}{c}\text { Rhizo } \\
\text { Sphere }\end{array}$ & $\begin{array}{c}\text { Phylo } \\
\text { sphere }\end{array}$ & $\begin{array}{c}\text { Rhizo } \\
\text { Sphere }\end{array}$ & $\begin{array}{c}\text { Phylo } \\
\text { sphere }\end{array}$ \\
\hline Evenness index & 0.720 & 0.781 & 0.800 & 0.839 & 0.375 & 0.314 \\
\hline Diversity index & 1.332 & 1.560 & 1.696 & 1.889 & 0.562 & 0.600 \\
\hline Species richness index & 1.864 & 1.924 & 2.171 & 2.731 & 0.721 & 0.834 \\
\hline Total individual number & 5 & 8 & 10 & 9 & 4 & 11 \\
\hline
\end{tabular}

Commonly typical of pesticide was applied in local shallot field divide into two form: insecticides and fungicides. Insecticides consist of eight group divided into seven group was classified as II and remain as Ib. The II is quite dangerous and Ib is very dangerous (WHO, 2008). Insecticides has impact directly and indirectly, they are very dangerous for natural enemies surrounding the field (Cloyd, 2006). The direct effects was associated with pests death or their offspring survival over a period of time, 24 to 96 hours (Stapel et al., 2000). The indirect effects was associated with physiological disorders and behavior of natural enemies (Desneux et al., 2007). Fungicides consist from five groups and four groups including class $\mathrm{U}$ and III. Nevertheless, fungicides very important because they are widely used as control tools in agricultural and horticultural production system (Wright and Verker, 1995).

Comparing the number of isolates found in differences frequency application of pesticides was showed influence on the type and number of isolates fungi. The frequency of low pesticide application into rhizosphere, there are all endophytic fungi such as $A$. niger, A. flavus, Gliocladium sp. and Penicillium sp., only Fusarium sp. as pathogenic fungi. Trichoderma spp. as endophytic fungi was found on field in moderate pesticide application. Local shallot field with high pesticide application, dominant species were identified with low fungi diversity (diversity index $<1$ ). Nirwanto and Mujoka (2009) stated that diversity of phylospheric saprobial of fungi species in shallot plantations was relatively low due to the use of pesticides. A. flavus and Penicillium sp. as endophytic fungi were not found in field with low and medium of pesticides application. Fusarium sp. is a pathogenic fungi found in the atmosphere at all field of pesticide application. This indicate Fusarium sp. have been resistance to the pesticide application in the $\mathrm{s}$ study area. According to Christanti et al., (2013); Paramita et al., (2014) and Rao et al., (2015) state that the continuous of fungicides application, especially systemic fungicides will product new strains target to resistance. This is caused contain variety of chemicals has a systemic effect.

Khan (2003) state that presence of Trichoderma spp. and A. niger as endophytic fungi on all fields applied by pesticides is important to develop as biological agents. The reason is fungi has a life-resistant nature with varying levels of pesticide residues. This is opportunity working more effectively and supported by appropriate environmental factors and not causing ecosystem changes and cheaper formulated for farmers. Madigan and Martinko (2006) report that A. niger from Ascomycetes found abundantly in nature. Usually A. niger collected and isolated from soil, plant residues and in the room. Trichoderma spp. is a type of fungi has same 
class with $A$. niger working as antifungal activities, commonly found in woody substrates on forest and agricultural land (Samuels, 2006). Santoso et al., (2007) mentioning that Trichoderma spp. very potential to be used as biological control for future management diseases in local shallot in Palu valley.

The continuous pesticides application to local shallot plants in Palu valley caused negative impact on antagonistic fungi presence by reducing their abundance, diversity and evenness. The most phenomenal of these impacts is the emergence of resistant fungi such as Fusarium sp. as pathogenic fungi in all frequency of pesticide application. However, the emergence of Trichoderma spp. and $A$. niger as endophytic fungi on all fields applied by different pesticides, gave important meaning in this study. Their existence could be developed into biological agents, because the fungi has a life-resistant nature with a variety of pesticide residues.

\section{Acknowledgement}

Financial support was provided by DRPM Ministry of Research, Technology and Higher Education, Republic of Indonesia with contract number 1739/UN4.21/PL.01.10/ 2019.

\section{References}

Basuki, R. S., 2011. Farmers knowledge and effectiveness of insecticide uses by farmers in controlling Spodoptera exigua on shallots in Brebes and Cirebon. Indon J Agric 4: 22-32.

Christanti S., Hartono, S., Nasrun dan Sukamto. 2013. Pengendalian penyakit budok dengan fungisida dan deteksi residu pada daun nilam / Control of budok disease with fungicides and detection of residue in patchouli leaves.
Jurnal Fitopatologi Indonesia, 9(3): 7884.

Cloyd, R. A., 2006. Compatibility of insecticides with natural enemies to control pests of greenhouses and conservatories. J Entomol Sci 41: 189197.

Cook, R.J. and Baker K.F., 1983. The Nature and Practice of Biological Control of Plant Pathogens. APA Press The American Phytopathological Society. St. Paul, Minnesota.

Desneux N., Decourtye, A., and Delpuech, J. M., 2007. The sublethal effects of pesticides on beneficial arthropods. Ann. Rev. Entomol 52: 81-106.

Jaya, K., Ardi, M., Sjam S., dan Gufran D. D., 2015. Onion farmers' behavior in Ecosystem-Based Pest (EBP) control in Sigi district of Central Sulawesi Province. Man in India, 95:649-659. Serial Publication.

Joko, T., Anggoro, S., Sunoko, H. R., and Rachmawati, S., 2017. Pesticides usage in the soil quality degradation potential in Wanasari Subdistrict, Brebes, Indonesia. Appl. Environ Soil Sci: 1-7.

Khan, M. Z., 2003. Effect of pesticides on biodiversity: comparison of malathion with biosal on protein contents in Calotes versicolor. J. Nat. Hist.Wildl. 2(1): 25-28.

Ludwig, J.A. and Reynolds, J. F., 1988. Statistical Ecology. A Primer on Methods and Computing, John Wiley \& Sons.

Madigan, M.T., and Martinko, J. M., 2006. Brock Biology of Microorganisms $11^{\text {th }}$ Eds. New Jersey: Pearson Education.

Magurran, E. A., 1983. Ecological Diversity and Its Measurement. Chapman and Hall.

Marlitasari, E., Sulistyowati, L., dan Kusuma, R. R., 2016. Hubungan ketebalan lapisan epidermis daun terhadap infeksi jamur Alternaria porrii penyebab 
penyakit bercak ungu pada empat varietas bawang merah / Relationship between thickness of leaves epidermal layer and ability fungi infection of Alternaria porrii caused purple blotch disease at four variety of shallot. Jurnal HPT. 4 (1): 8 - 16.

Maskar, Chatijah and Asni A., 1999. Pengujian paket teknologi budidaya bawang merah varietas lokal di lahan kering / Testing shallot cultivation technology for local varieties on dry land. Balai Pengkajian Teknologi Pertanian Biromaru. pp. 25-28.

Nelly N., Reflinaldon and Amelia K. 2015. Diversity of predators and parasitoids on shallot cultivation: A case study in the Alahan Panjang Region, West Sumatra. Pros Sem Nas Masy Biodev Indon 1: 1005-1010.

Nirwanto, H., 2007. Ketahanan populasi varietas bawang merah terhadap epidemi penyakit bercak ungu Alternaria porri di daerah Batu Malang / The population resistance of shallot varieties to epidemics of disease Alternaria porrii the purple blotch disease in Batu Malang. [Disertasi]. PPSUB Universitas Brawijaya. Malang.

Nirwanto,H., dan Mujoka, T., 2009. Eksplorasi dan Kajian Keragaman Jamur Filoplen pada Tanaman Bawang Merah: Upaya Pengendalian Hayati Terhadap Penyakit Bercak Ungu (Alternaria porrii) / Exploration and Study Diversity of Filoplen Mushroom Shallot Plant: Biological Control Efforts against Purple Blotch Disease (Alternaria porrii). Bahan Seminar Nasional Pada Fak.Pertanian dan LPMM UPM Veteran Jawa Timur.

Paramita, N. R., Sumardiyono, C., dan Sudarmadi, 2014. Pengendalian kimia dan ketahanan Colletotorichum spp. terhadap fungisida Simoksanil pada cabai merah / Chemical control and resistance of Collectotrichum spp. against Cymoxanil fungicide on red pepper. Jurnal Perlindungan Tanaman Indonesia, 18(1):41-46.

Rao, A.S., Ganeshan, G., Ramachandra, Y. L., and Cethana, B. S., 2015. Field evaluation of fungicides against Alternaria porrii (Ellis) Cif., causing purple blotch of onion (Allium cepa L.). International Journal Agriculture, Environment and Biotechnology. 8(1) March 2015: 89 - 95.

Ratnawati dan Idris, 2010. Pengaruh Berbagai Dosis Radiasi Sinar Gamma Co-60 Terhadap Perkembangan Penyakit Bercak Ungu Pada Tiga Varietas Bawang Merah Yang Diinokulasi Mikoriza Arbuskula / The influence rays radiation doses of various Gamma Co-60 on the development of purple blocth diseases in three variety of shallot inoculated by arbuscular mycorrhiza. Jurnal Kiat Unisa Palu, 2(2). Edisi Desember 2010.

Rusdam, M., Rosmini dan J. Panggeso, 2013. Uji antagonisme Trichoderma $s p$. terhadap jamur patogen Alternaria porri penyebab penyakit bercak ungu pada bawang merah secara in-vitro / Antagonism test Trichoderma sp. against fungi pathogens causing purple blotch disease Alternaria porrii on shallot by in-vitro. e-J. Agrotekbis 1 (2) Juni 2013: 140-144.

Saidah, Syafruddin dan Sakka Samudin, 2014. Karakteristik Bawang Merah di Lembah Palu / Characteristic of shallot in Palu Valley. Makalah Seminar Nasional Masyarakat Biodiversitas Indonesia, Depok, Jawa Barat.

Samuels, G. J., 2006. Trichoderma: systematics, the sexual state, and ecology. Phytopathology 96(2) February 2006: 195-206. doi: 10.1094/PHYTO-96-0195.

Santoso, S.E., Soesanto, L. dan Dwi 
Haryanto, T.A. 2007. Penekanan HayatiPenyakit Moler Pada Bawang Merah Dengan Trichoderma harzianum, Trichoderma koningii, dan Pseudomonas fluorescens P60 / Biological suppression of moler disease on shallot by Trichoderma harzianum, Trichoderma koningii and Pseudomonas fluorescens P60. J. HPT Tropika. Vol. 7, No. 1: 53-61. doi: http://dx.doi.org/10.23960/j.hpt.17\%25p

Semangun H. 2006. Penyakit-Penyakit Tanaman Hortikultura di Indonesia / Diseases of Horticulture Plant in Indonesia. Gadjah Mada University Press, Yogyakarta.

Shahabuddin, Anshary A., and Gellang A., 2012. Tingkat serangan dan jenis lalat pengorok daun pada tiga varietas lokal bawang merah di Lembah Palu Sulawesi Tengah / Infestation intencity and leafminer species on three local varieties of onion crops in Palu Valley, Central Sulawesi. J. HPT Tropika 12: 153

161. doi:http://dx.doi.org/10.23960/j.hpt.212 153-161.

Stapel, J. O., Cortesero, A. M and Lewis, W. J., 2000. Disruptive sublethal effects of insecticides on biological control: Altered foraging ability and life span of a parasitoid after feeding on extrafloral nectar of cotton treated with systemic insecticides. Biol Control 17: 243-249.

Waryanto B, Chozin, M.A., Dadang and Putri, E. I. K., 2014. Environmental efficiency analysis of shallot farming: astochastic frontier translog regression approach. J Biol Agric Healthcare 4: 87 $-100$.

WHO, 2005. The WHO recommended classification of pesticides by hazard and guidelines to classification 2004. World Health Organization, Geneva, Switzerland.

Wright, D. J., Verker, R. H. J., 1995. Integration of chemical and biological control systems for arthropods: Evaluation in a multitrophic context. Pestic Sci 44: 207-218.

\section{How to cite this article:}

Ratnawati Ratnawati, Sylvia Sjam, Ade Rosmana and Untung Surapati Tresnaputra. 2019. Impact of Pesticides on the Diversity of Fungi at Local Shallot in Palu, Indonesia. Int.J.Curr.Microbiol.App.Sci. 8(08): 730-738. doi: https://doi.org/10.20546/ijcmas.2019.808.083 